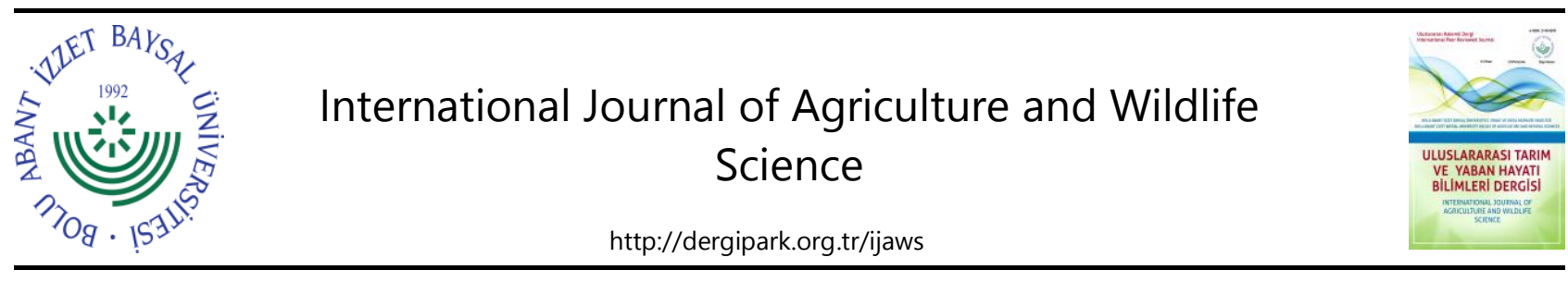

Research Article

\title{
A Research on Mould and Aflatoxin Contamination Levels of Feeds Used in Trout Farms of Adana (Turkey) ${ }^{*}$
}

\author{
Özgür Gölge ${ }^{1 *}(\mathbb{D}), \quad$ Ayşegül Aktüre ${ }^{2}$ (D) $\quad$ Rozelin Aydın ${ }^{3}$
}

${ }^{1}$ Alanya Alaaddin Keykubat University, Faculty of Tourism, Department of Gastronomy and Culinary Arts, Antalya, Turkey ${ }^{2}$ Ministry of Agriculture and Forestry, General Directorate of Food and Control, Food Control Laboratory, Adana, Turkey

${ }^{3}$ Adana Alparslan Türkeş Science and Technology University, Faculty of Engineering, Department of Bioengineering, Adana, Turkey

Received: 01.12.2020 Accepted: 13.01.2021

\begin{abstract}
Keywords:
Aflatoxin, feed, mould, trout fish

*Corresponding author ozgurgolge@hotmail.com

Abstract. This research was conducted to analyze the mould counts and aflatoxin contamination levels of different types and sizes of feed used in trout farms of Adana. Totaly 33 different feeds supplied from 15 trout farms of Adana (Turkey) were analysed for moulds and aflatoxins ( $A F B_{1}, A_{F B}, A F G_{1}$ and $A F G_{2}$ ) between July-December 2010. To identify mould counts; the samples were incubated in the aerobic conditions at $25 \pm 1{ }^{\circ} \mathrm{C}$ for five days by using Dichloran Rose Bengal Chloramphenicol Agar (DRBC). Aflatoxins were determined by using liquid-solid extraction and recoveries were obtained $70.00 \%$ to $112.20 \%$. The precision of measured values of mould and aflatoxin analysis methods was calculated with the results of repeatability and reproducibility. The bias, expressing the accuracy value, varies between 4.312 and 12.909. Although moulds were found in 12 of 33 analysed samples (36.30\%): aflatoxins were determined 8 out of 33 analysed samples (24.25\%). Positive sample's range were $3.08-4.86 \log _{10} \mathrm{kob} \mathrm{g}^{-1}$ moulds and $0.21-0.90 \mu \mathrm{g} \mathrm{AFB} \mathrm{kg}^{-1}$ ( $\mathrm{ppb}$ ) of trout feeds. As a result, this research showed that none of the trout feeds used in trout farms of Adana has aflatoxins above Turkey legal limits.
\end{abstract}

\section{Adana'da Alabalık Çiftliklerinde Kullanılan Yemlerin Küf ve Aflatoksin Kontaminasyon Düzeyleri Üzerine Bir Araştırma}

Anahtar kelimeler:

Aflatoksin, yem, küf, alabalık
Özet. Bu araştırma, Adana'daki alabalık çiftliklerinde kullanılan farklı tür ve büyüklükteki yemlerin küf küf, ve aflatoksin kontaminasyon düzeylerinin belirlenmesi amacıyla gerçekleştirilmiştir. Adana'daki on beş alabalık çiftliğinden tedarik edilen 33 farklı alabalık yeminin, Temmuz-Aralık 2010 döneminde küf ve aflatoksin $\left(\mathrm{AFB}_{1}, \mathrm{AFB}_{2}, \mathrm{AFG}_{1}\right.$ ve $A \mathrm{FG}_{2}$ ) analizleri gerçekleştirilmiştir. Küf sayılarını belirlemek için; yem örnekleri Dichloran Rose Bengal Chloramphenicol Agar (DRBC) kullanılarak aerobik koşullarda $25 \pm 1$ - C'de beş gün inkübe edilmiştir. Aflatoksinler sıvı-katı ekstraksiyon tekniği kullanılarak tespit edilmiş ve geri kazanım oranları $70 \%$ ile $112.20 \%$ arasında bulunmuştur. Küf ve aflatoksin analiz metotlarının kesinlik değerleri tekrarlanabilirlik ve tekrar üretebilirlik sonuçlarından hesaplanmıştır. Doğruluk değerini ifade eden bias, 4.312 ile 12.909 arasında değişmektedir. 33 yem numunesinin 12'sinde küf bulunurken (36.30\%); 8 'inde aflatoksin tespit edilmiştir (24.25\%). Pozitif numuneler için aralıklar 3.08$4.86 \log 10 \mathrm{kob} \mathrm{g}^{-1}$ küf ve 0.21-0.90 $\mu \mathrm{g}$ AFB1 $\mathrm{kg}^{-1}$ (ppb)'dir. Sonuç olarak, bu araştırma Adana'da incelenen alabalık çiftliklerinde kullanılan alabalık yemlerinin hiçbirisinde Türkiye yasal limitlerinin üzerinde aflatoksin bulunmadığını göstermiştir.

** This abstract was presented in International Conference on Raw Materials to Processed Foods and published in Book of Abstracts. s: 23, 11-13 Nisan 2018, Antalya / TURKEY. 


\section{INTRODUCTION}

Due to reduction of fish population in natural resources, aquaculture has been increasing in Turkey along with other countries in the world. Although fish farming in Turkey has extensive water resources it is still not at the expected level, but developments are promising. Adana, which is the center of the current research, is a modest example of increasing the number of trout farms in the provinces and districts in recent years.

In parallel with this increase; trout feed industry has been growing as well. Trout feed is generally; produced from corn, corn gluten meal, wheat, wheat bran, soybean oil, soybean expeller, fish meal and fish oil by formulating for different life stages and presented as compact pellets and in different sizes (Greco et al., 2015). Since their chemical and nutritional properties are related to their activity, approximative compound of trout feed ingredients must be known (Anater et al., 2016).

Depending on the type of fish grown and the location of the farm; the production of different types of feed and the use of new techniques have become a necessity. For the production of quality, clean and economical feed; providing appropriate conditions is very important. Because; quality feed means trout with high nutritional value and no microbiological or toxicological risks (Kop and Korkut, 2002).

Moulds are defined as nucleated microorganisms (eukaryotes) included in the class of Mycota or Fungi and they are usually referred to as fungi. They can easily grow anywhere as they are plenty in nature and are not prone to develop (Şahin and Korukluoğlu, 2000). They cause an unfavorable sour smell, deterioration, reduction in dry matter, nutrient and economic loss of the product that they grow on; more than that they can produce different types of mycotoxins (Maciorowski et al., 2007; Faria et al., 2017).

In the event of moist content being over $14.5-15.5 \%$ in raw material or end product in storage, fungi start to grow. Under certain temperatures and moistures, fungi produce mycotoxins. The fish that are fed with feed stuff that include such elements are observed to lose weight and also die in some cases (Kop and Korkut, 2002).

In the process of metabolic activities for their feeding, fungi are capable of forming an enormous number and variety of materials. The metabolic forms that fungi produce are classified as primary and secondary metabolics depending on formation amounts. Among primary metabolic formations are certain alcohols, organic acids, enzymes and others while secondary metabolic formations include mycotoxins, the most dangerous of which are Aspergillus are Penicillium (Sahin and Korukluoglu, 2000).

Aflatoxins are the most crucial group and important secondary toxic metabolites produced by species of Aspergillus and Penicillium. These fungal toxins are hepatotoxic and cause mutagenic and teratogenic diseases in such as liver toxicity, liver cancers and protein lackness in humans and animals (Mohammadi et al., 2018). Aflatoxins grow due to various reasons such as feed or food stuff not being harvested in time, inefficient storage conditions, high levels of moisture in products and low hygiene during processing of feed or food stuff. An average of $25 \%$ of products harvested worldwide is contaminated by mycotoxins to varying degrees (Aydın et al., 2003).

Fish are highly sensitive to feedstuff-based toxins. Trouts are particularly affected by aflatoxins caused by feed stuff with fungi. Unsaturated fats that are easily oxidized cause the feedstuff to go bad, which cause Salmonid type of fish to have steatorrhoea hepatosis (fatty liver) and this finally causes anemia (Atesoglu, 1999).

Commonly seen among rainbow trout; aflatoxin intoxication leads to tumor growth in liver. Even if fishs consume feeds containing 10-20 ppm levels of aflatoxins; parenchymal cells grow and become irregular (Ekici, 2017). Aflatoxins occur as a result of moulding in feed sacks. Tumor growth in livers of fish that are fed this feedstuff could be lethal. In order to prevent moulding in feed sacks, storages are supposed to be dry, aired, dark and cool. Maximum of 4 or 5 packages of feed sacks should be piled on to each other, each raw of packages should not contact and they should be placed on shelves $5-10 \mathrm{~cm}$ high above the ground (Aydın, 2007).

This research is designed in order to detect presence of mould and determine aflatoxin amounts of trout feeds in different types and sizes in trout farms of Adana.

\section{MATERIAL AND METHOD}

\section{Samples}

Between July 2010-December 2010, 33 feed samples (each about $500 \mathrm{~g}$ ) were supplied from 15 trout farms in Adana (Turkey). Samples were carried to the microbiology and mycotoxin laboratory in a thermos. All samples were milled in the stainless-steel blender (Waring, Connecticut, USA) to provide standard particle size and kept in glass jars and deep freeze till test it. All samples were tested until expiration date of trout feeds (Golge et al., 2013). 


\section{Chemicals and Reagents}

While Dichloran Rose Bengal Chloramphenicol Agar, sodium chloride, nitric acid and potassium bromide were suplied by Merck (Darmstadt, Germany); acetonitrile and methyl alcohol (HPLC grade) were procured by SigmaAldrich (St. Louis, MO, USA). The AflaPrep immunoaffinity columns were produced by R-Biopharm Rhone (Glasgow, Scotland) and supplied from Sincer (Izmir, Turkey). $18.2 \mathrm{M} \Omega \cdot \mathrm{cm}$ ultrapure water was produced with Millipore Synergy water purification system (Merck, Molsheim, France). AFs standards were produced by RBiopharm Rhone (Glasgow, Scotland) and supplied from Sincer (Izmir, Turkey), (Aflastandart Solution, catalog no. P22). AFs mix contained $250 \mathrm{ng} A F B_{1}, A_{F B}, A_{F G}$ and $A F G 2$, respectively in $1 \mathrm{ml}$ of methyl alcohol.

\section{Enumeration of Mould and Calculation}

Mould analysis is carried out by using Dichloran Rose Bengal Chloramphenicol Agar (DRBC) and incubating petri boxes under aerobe conditions for five days under $25 \pm 1{ }^{\circ} \mathrm{C}$ (Anon, 2001). Petri colonies between 10-150 have been enumerated and results have been calculated. Numbers are presented as $\mathrm{kob} \mathrm{g}^{-1}$. For calculation the formula below has been used. The calculated results have been converted into $\log _{10} \mathrm{kob} \mathrm{g}^{-1}$.

$$
\begin{aligned}
& \mathrm{N}=\Sigma C /[(1 \times \mathrm{n} 1)+(0.1 \times \mathrm{n} 2) \times \mathrm{d}] \\
& \mathrm{N}=\text { Colony number } \mathrm{g} \text { or } \mathrm{ml} \\
& \Sigma C=\text { Total of colonies in petris } \\
& \mathrm{n} 1=\text { Number of petri number in the first dilution } \\
& \mathrm{n} 2=\text { Number of petri number in the second dilution } \\
& \mathrm{d}=\text { Dilution factor of the first numbered petri }
\end{aligned}
$$

\section{Preparation of Standard Solutions}

AFs solution was adulterated with methyl alcohol to make concentrations of $10 \mathrm{ng} \mathrm{ml}^{-1}$ for AFs. Different standard levels $\left(0.1,0.2,0.4,1.2,2,4,5 \mathrm{ng} \mathrm{ml}^{-1}\right)$ were obtained by using this mother solution. All aflatoxin standarts were refreshed once a month and used to create calibration table of AFs analysis and recovery studies.

\section{Analysis of Feed Samples with Immunoaffinity Column}

Aflatest HPLC procedure was applied to extract and clean-up with IAC the AFs from trout feed samples (Anon., 1999). 50 gram of feed was stirred with $5 \mathrm{~g} \mathrm{NaCl}$ and $100 \mathrm{ml}$ solvent ( $80 \%$ methyl alcohol: $20 \%$ water) in a blender and milled and homogenized for $2 \mathrm{~min}$. After homogenization; the extract was filtered with prefolded paper. 10 $\mathrm{ml}$ filtrate was mixed with $40 \mathrm{~mL}$ ultrapure water. This mixture was filtered again by using glass microfiber filter. $10 \mathrm{ml}$ filtrate was undergone through the immunoaffinity column at a speed of 2-3 $\mathrm{ml} / \mathrm{min}$. Then, IAC was washed with $10 \mathrm{ml}$ ultrapure water. Finally, bounded aflatoxins eluted slowly with $1 \mathrm{ml}$ methyl alcohol by pushing air through the IAC to obtain the last drops of eluate in $1.5 \mathrm{ml}$ vial and diluted with $1 \mathrm{ml}$ ultrapure water.

\section{HPLC Equipment and Chromatographic Conditions}

Compartments of Agilent 1100 HPLC were; isocratic pump, degasser, autosampler, column oven and fluorescence detector (Agilent, California, USA). HPLC mobile phase contained water-acetonitrile-methyl alcohol $(6: 2: 3, \mathrm{v} / \mathrm{v} / \mathrm{v})$ including $0.12 \mathrm{~g} \mathrm{l}^{-1}$ potassium bromide and $350 \mathrm{\mu l}^{-1}$ nitric acid $(4 \mathrm{M})$ and the flow speed was $1 \mathrm{ml}$ $\mathrm{min}^{-1}$. ODS 2 HPLC column $(250 \times 4.6 \mathrm{~mm})$ was used for chromatographic separations. The column temperature was $25^{\circ} \mathrm{C}$, injection volume was $100 \mu \mathrm{l}$. Improved chromatography provides the fluorescent responses of $\mathrm{AFB}_{1}$ and $A F G_{1}$ with post column derivatization. Potassium bromide and Kobracell ${ }^{\circledR}$ (R-Biopharm AG, Darmstadt, Germany) were used for derivatization. The fluorescence detector was set to wavelengths of $360 \mathrm{~nm}$ for excitation and $430 \mathrm{~nm}$ for emission. Total analysis period was about $14 \mathrm{~min}$. and the retention times of $A F B_{1}, A F B_{2}, A F G_{1}$ and $\mathrm{AFG}_{2}$ were $10.2,9.2,8.2$ and 6.5 min., respectively.

\section{Method Verification Procedures}

In spite of precision parameter was applied to evaluate the method performance of mould analysis; linearity, precision, accuracy, limits of detection (LOD) and limits of quantification (LOQ) were applied to ensure the method verification of $A F_{s}$. Linearity was asigned by injecting triplicate $A_{s}$ standard solutions $(0.1,0.2,0.4,1.2,2,4,5 \mathrm{ng}$ $\mathrm{ml}^{-1}$ ). The linearity was interpreted by linear regression analysis using the least squares method.

According to IUPAC Orange Book Section 18.4.3.17; to calculate the LOD and LOQ of the Aflatoxins, blank trout feed samples were spiked $0.1 \mathrm{ng} \mathrm{ml}^{-1}$ for $A F B_{1}, A F G_{1}, A F B_{2}$ and $A F G_{2}$, respectively. Spiking was applied in ten replicates. Finally; these formulas were used to calculate $L O D$ and $L O Q: L O D=3 \times$ standard deviation, $L O Q=10$ x standard deviation (Curie, 1995). 
For recovery practice; blank trout feed samples were spiked at $1 \mathrm{ng} \mathrm{ml}^{-1}$ for all AFs. Spiking was applied in total twenty replicates by two person. Blank and spiked samples were extracted, cleaned-up and injected in vials to the HPLC by the same analyst.

The accuracy was calculated with trueness (bias). To determine truness; recovery datas were used. This formula was used to calculate trueness: Bias $=[(X i-X t) / X t] \times 100$

$\mathrm{Xi}$ : Expected amount, $\mathrm{Xt}$ : Determinated amount.

The precision of international standard mould analysis method was calculated from intra-day repeatability with limit of intra-day repeatability $(r=2.8 \times R S D)$ and inter-day reproducibility with limit of inter-day reproducibility ( $R=2.8 \times R S D$ ) by ten-replicated analysis for each person (total three person) of the samples, respectively. For the precision of AFs; total twenty samples spiked with AFs at $1 \mathrm{ng} \mathrm{ml}^{-1}$ were analysed on two different days by two persons. The precision was evaluated in terms of intra-day repeatability with limit of intraday repeatability $(r=2.8 \times R S D)$ and inter-day reproducibility with limit of inter-day reproducibility $(R=2.8 \times R S D)$.

\section{RESULTS AND DISCUSSION}

\section{Method Verification Results}

In mould analysis, reproducibility and repeatability relative standard deviations obtained with verification studies were found to be suitable according to "validation parameters acceptance criteria" stated in AOAC sources.

The linearity range for AFs, the correlation coefficient $\left(r^{2}\right)$, linear regression equation, LOD and LOQ for each aflatoxin are presented in Table 1. The calibration curves were linear with correlation coefficients $\left(r^{2}\right)$ of 0.9999 , $0.9999,0.9992$ and 0.9995 for $\mathrm{AFB}_{1}, \mathrm{AFB}_{2}, \mathrm{AFG}_{1}$ and $\mathrm{AFG}_{2}$, respectively. In addition, RSD of calibration curves were $0.1110,0.0801,0.2436$ and 0.1977 for $A F B_{1}, A_{F B}, A F G_{1}$ and $A F G_{2}$, respectively. The LODs and LOQs values were $0.104-0.140 \mathrm{\mu g} \mathrm{kg}^{-1}$. These values were similar to those calculated previously results for AFs (Fu et al., 2008; Kabak, 2012; Golge et al., 2013).

Table 1. Linearity, correlation coefficient, linear regression equation of calibration curve, LOD and LOQ values for AFs. Çizelge 1. Aflatoksinlerin kalibrasyon eğrisinin linearite, korelasyon katsayısı, LOD ve LOQ değerleri.

\begin{tabular}{lllll}
\hline Toxin name & Linearity range $\left(\mu \mathbf{g ~ I}^{-1}\right)$ & $\boldsymbol{r}^{2}$ & $\begin{array}{l}\mathbf{L O D}^{\mathbf{a}} \\
\left(\boldsymbol{\mu g} \mathbf{~ k g}^{-1}\right)\end{array}$ & $\begin{array}{l}\mathbf{L O Q}^{\mathbf{b}} \\
\left(\boldsymbol{\mu g} \mathbf{~ k g}^{-1}\right)\end{array}$ \\
\hline $\mathrm{AFB}_{1}$ & $0.1-5$ & 0.99994 & 0.104 & 0.111 \\
$\mathrm{AFB}_{2}$ & $0.1-5$ & 0.99999 & 0.104 & 0.110 \\
$\mathrm{AFG}$ & $0.1-5$ & 0.99920 & 0.105 & 0.115 \\
$\mathrm{AFG}$ & $0.1-5$ & 0.99951 & 0.113 & 0.140 \\
\hline
\end{tabular}

$r^{2}$ : correlation coefficient

${ }^{a}$ Limit of detection

${ }^{b}$ Limit of quantification

The recovery results and precision (intra-day repeatability as limit of intra-day repeatability ( $r$ ) and inter-day reproducibility with limit of inter-day reproducibility (R) of the AFs analytical method and precision (intra-day repeatability as limit of intra-day repeatability $(r)$ and inter-day reproducibility with limit of inter-day reproducibility $(\mathrm{R})$ of the mould analysis method are showed in Table 2.

Table 2. The recoveries, precision (repeatability, reproducibility), truness (bias) of AFs. Çizelge 2. Aflatoksinlerin geri kazanım oranları, kesinlik (tekrarlanabilirlik, tekrarüretilebilirlik), doğruluk değerleri.

\begin{tabular}{|c|c|c|c|c|c|c|}
\hline Toxin name & $\begin{array}{l}\text { Amount } \\
\left(\mu \mathrm{g} \mathrm{kg}^{-1}\right) \\
(n=20)\end{array}$ & $\begin{array}{l}\text { Recovery } \\
(\%)\end{array}$ & $\begin{array}{l}\text { Repeatability }^{a} \\
\text { RSD (\%) for first } \\
\text { person }\end{array}$ & $\begin{array}{l}\text { Repeatability } \\
\text { RSD (\%) for } \\
\text { second person }\end{array}$ & $\begin{array}{l}\text { Reproducibility }{ }^{\text {bSD }} \\
(\%)\end{array}$ & $\begin{array}{l}\text { Bias }^{c} \\
\text { RSD (\%) }\end{array}$ \\
\hline $\mathrm{AFB}_{1}$ & 1 & 93.17 & 0.193 & 1.061 & 0.585 & 7.296 \\
\hline $\mathrm{AFB}_{2}$ & 1 & 105.79 & 0.129 & 0.087 & 0.129 & 5.482 \\
\hline $\mathrm{AFG}_{1}$ & 1 & 88.13 & 0.454 & 0.409 & 0.414 & 13.507 \\
\hline $\mathrm{AFG}_{2}$ & 1 & 90.89 & 0.395 & 0.291 & 0.356 & 10.011 \\
\hline
\end{tabular}

\footnotetext{
a Repeatability was calculated by analysis of ten replicate samples at one concentration level of each toxin on the same day by two persons.

${ }^{b}$ Reproducibility was calculated by analysis of ten replicate samples at one concentration level of each toxin on the different two days by two persons.

' Bias was calculated by analysis of ten replicate samples at one concentration level of each toxin on the on the different two days by two persons.
} 
Table 3. The precision (repeatability, reproducibility) of mould analysis method.

Çizelge 3. Küf analiz metodunun kesinlik (tekrarlanabilirlik, tekrarüretilebilirlik) değerleri.

\begin{tabular}{clll}
\hline $\begin{array}{l}\text { Intra-day repeatability } \\
\left(\mathbf{S}_{\mathbf{r}}\right) \text { for first person }\end{array}$ & $\begin{array}{l}\text { Intra-day repeatability } \\
\left(\mathbf{S}_{\mathbf{r}}\right) \text { for second person }\end{array}$ & $\begin{array}{l}\text { Intra-day repeatability }^{\mathbf{a}} \\
\left(\mathbf{S}_{\mathbf{r}}\right) \text { for third person }\end{array}$ & $\begin{array}{l}\text { Inter-day reproducibility }^{\mathbf{b}} \\
\left(\mathbf{S}_{\mathbf{R}}\right)\end{array}$ \\
\hline 0.039 & 0.036 & 0.031 & 0.048 \\
\hline
\end{tabular}

a Repeatability was calculated by analysis of ten replicate samples at two concentration levels and two parallels on the same day by three persons.

b Reproducibility was calculated by analysis of ten replicate samples at two concentration levels and two parallels on the different two days by three persons.

\section{Analysis of Trout Feed Samples}

Mould analysis results of trout feeds are summarized on Table 4. Out of 33 feed samples, 21 samples (63.6\%) were found not to contain mould on the other hand in 12 samples (36.3\%) had mould. Results of the feed samples that contained mould varied between $<10$ to and $4.86 \log _{10} \mathrm{kob} \mathrm{g}^{-1}$ were very similar to other values determined by Greco et al. (2015). Extrude, pres-pelet growing and stem feeds did not include mould. Highest concentration of mould production was seen in growth feeds with $3 \mathrm{~mm}$ diameter. The obtained results indicate that feed type and diameter are considerable in mould growth.

Table 4. Mould analysis results of feed samples.

Çizelge 4. Yem örneklerinin küf analizi sonuçları.

\begin{tabular}{lllll}
\hline $\begin{array}{l}\text { Feed } \\
\text { No }\end{array}$ & $\begin{array}{l}\text { Feed } \\
\text { Type }\end{array}$ & $\begin{array}{l}\text { Feed Diameter } \\
(\mathbf{m m})\end{array}$ & $\begin{array}{l}\text { Period of } \\
\text { purchase }\end{array}$ & $\begin{array}{l}\text { Mould Amount } \\
\text { (log } \mathbf{\text { kob g }} \mathbf{- 1} \text { ) }\end{array}$ \\
\hline 1 & Growth & 4 & July 2010 & 3.94 \\
2 & Growth & 3 & July 2010 & 4.00 \\
3 & Fry & 2 & July 2010 & 3.79 \\
4 & Growth & 2 & August 2010 & 4.20 \\
5 & Growth & 3 & August 2010 & 3.90 \\
6 & Growth & 3 & August 2010 & 4.86 \\
9 & Growth & 8 & August 2010 & 4.00 \\
10 & Fry & 2 & August 2010 & 3.49 \\
14 & Growth & 3 & September 2010 & 3.08 \\
18 & Growth & 3 & October 2010 & 3.30 \\
25 & Growth & 2 & November 2010 & 4.15 \\
27 & Growth & 4 & November 2010 & 3.78 \\
\hline
\end{tabular}

When aflatoxin $B_{1}$ levels are considered, as it is the most toxic group among aflatoxins; 25 samples were reported to have aflatoxin $B_{1}$ under limit of detection (LOD). 8 feed samples (24.25\%) on the other hand, have various levels of aflatoxin $B_{1}$ between $0.21 \mathrm{ppb}$ and $0.90 \mathrm{ppb}$. Although these results confirm the previous studies by Kaymak 2000; Yaroglu and Gul, 2007; Merako, 2010); AFB1 levels in our study were smaller than other studies (Altug and Beklevik, 2003; Goncalves et al., 2018).

Kaymak (2000) studied aflatoxin analysis of 59 feed samples from different feed factories in Turkey. According to the results of his analysis, $47.45 \%$ of the feed samples did not contain aflatoxin while $52,50 \%$ had various levels of aflatoxins. The values he found are not above Turkey's limits like our study. At the same time, he concluded that technologies used in feed production (Extrusion, Pelletization) are not a defining factor whether to increase or decrease aflatoxin contents.

Altug and Beklevik (2003), in their research, detected total aflatoxins in 20 feed samples between $21.2-42.4$ $\mu \mathrm{g} \mathrm{kg}{ }^{-1}$, in 22 samples between $5.0-20.0 \mu \mathrm{g} \mathrm{kg}^{-1}$ out of 85 trout feeds samples and concluded that in the rest of the 43 samples, no aflatoxins were traced. They discussed that fish feeds should be checked at fish farms periodically, product moisture and storing techniques should be followed, and similar studies should be carried out in larger scale under control. All these points are reported to prevent possible losses.

Yaroglu and Gul (2007), reached the conclusion in their study that fish feed in the province of Erzurum are sold out without waiting long and this prevents them from being exposed to high levels of moulding infestation and as a result, aflatoxin contamination levels observed to be lower.

Merako (2010), collected 27 samples from three different trout feeds use for three different periods (starter, fingerling, growing) in June, July and August 2010 to determine aflatoxin and heavy metal levels. According to aflatoxin analysis results: aflatoxin was found below the detection limit in all of 27 trout feeds.

Greco et al. (2015), analysed 28 trout feeds to determine fungal contamination and the occurence of mycotoxins in Mexico. While fungal count range was $<10$ to $4.56 \log _{10} \mathrm{kob} \mathrm{g}^{-1}$, the frequency of Aspergillus and 
Penicillum were found as $3.6 \%$ and $21.4 \%$ respectively. On the other hand, Aflatoxin $\mathrm{B}_{1}$ was determined in $50 \%$ of feeds as mean $2.82 \mathrm{ppb}$.

Goncalves et al. (2018), analysed 41 feed samples within the scope of BIOMIN mycotoxin survey programme during 2014. Aflatoxins, zearalenone, deoxynivalenol, fumonisin and ochratoxin A analysis in the all samples. Totaly; $76 \%$ of the samples had more than one mycotoxin, $59 \%$ of the samples were contaminated by AFs.

As seen in Table 5; AFB 1 levels in feed samples increased significantly in the period of September to December. Kaymak (2000), searched aflatoxin amounts considering periods and he stated that the highest values were observed in November.

Table 5. Aflatoxin $B_{1}$ contents of feed samples based on periods $\left(\mu \mathrm{g} \mathrm{kg}^{-1}\right)$.

Çizelge 5. Farklı zamanlarda yem örneklerinin Aflatoksin $B_{1}$ düzeyleri $\left(\mu \mathrm{g} \mathrm{kg}^{-1}\right)$.

\begin{tabular}{lllllll}
\hline Sample No & July & August & September & October & November & December \\
\hline 1 & ND & 0.21 & ND & ND & ND & ND \\
2 & ND & ND & 0.30 & ND & ND & ND \\
3 & ND & ND & 0.63 & ND & ND & ND \\
4 & ND & ND & 0.32 & ND & ND & ND \\
5 & ND & ND & 0.21 & ND & ND & ND \\
6 & ND & ND & ND & ND & ND & 0.90 \\
7 & ND & ND & ND & ND & ND & 0.70 \\
8 & ND & ND & ND & ND & ND & 0.80 \\
\hline
\end{tabular}

ND: Not detected

Furthermore, in three feed samples that did not contain aflatoxin, moulding was observed due to unsuitable storage conditions (high levels of moisture and temperature and others). With the aim of determining the type of mould, research was carried out and microscopic analysis of moulds presented that they are Penicillium type.

\section{CONCLUSION}

According to Turkey's legislation about aflatoxin level in feeds; maximum acceptable level is $10 \mu \mathrm{g} \mathrm{kg}^{-1}$ (Anon., 2014). None of trout feeds that were analyzed in studies were above aflatoxin limits. Major reasons for this could be attributed to the fact that majority of raw materials that trout feeds factories use are imported from abroad and these exported materials are strictly investigated before entering the country and also fish flour, an indispensable raw material of fish feed rations, is also exported to a great extent and due to the technologies that are used in production, toxin growth is considerably low.

In conclusion, it should be taken into consideration that under right conditions in feed storages, mould infestation growth will be a risk; therefore precautions against mould growth should be planned and taken in stages from transport to consumption in business. With this purpose, contamination must be prevented during transport to business, to keep feed packages closed and under right temperatures and moisture conditions to consider the production and expire date on the packages and not to store in great amounts. Pellet feeds should be preferred more as they are harder and are possible to store for an extended period of time. Also, it is vital to ask for analysis reports from dealers before purchasing feeds and to consume feeds in three months.

\section{CONFLICT OF INTEREST}

The authors declare that there is no conflict of interests regarding the publication of this article.

\section{DECLARATION OF AUTHOR CONTRIBUTION}

Ozgur Golge and Aysegul Akture discussed the research concept and designed the experiment. Rozelin Aydın and Aysegul Aktüre carried out the experiment. Ozgur Golge wrote the manuscript with the support of other researchers. 


\section{REFERENCES}

Altug, G., \& Beklevik, G. (2003). Level of aflatoxin in some fish feeds from fish farming processes, feed factories and imported feeds. Turkish Journal of Animal Science, 27, 1247-1252.

Anater, A., Manyes, L., Meca, G., Ferrer, E., Luciano, F. B., Pimpao, C. T., \& Font, G. (2016). Mycotoxins and their consequences in aquaculture: A review. Aquaculture, 451, 1-10.

Anonymous. (1999). Aflatest HPLC procedure for corn, grains and feeds. Aflatest Instruction Manual, Chapter 5.3., VICAM L.P., United States of America.

Anonymous. (2001). Yeasts, moulds and mycotoxins. Bacteriological Analytical Manual Online, Chapter 18, Food and Drug Administration, United States of America.

Anonymous. (2014). Yemlerde istenmeyen maddeler hakkında teblig (2014/11). Resmi Gazete: 28977. Gıda Tarim ve Hayvancilik Bakanligi, Ankara, Turkey.

Atesoglu, A. (1999). Total bacterial count, Enterobacteriaceae count and isolation of Enterobacteriaceae on fish feed and feed Stuffs. Bornova The Journal of Bornova Veterinary Science, 24(38), 71-78.

Aydın, R., Ozsan, E., \& Alptekin, Y. (2003.) Aflatoxin contamination and health risk in animal products. First National Mycotoxin Symposium, İstanbul.

Aydın, N. (2007). Mycotoxins and mycotoxicosis in animal health. Journal of Infection, 21(10), 37-46.

Curie, L. A. (1995). Nomenclature in evaluation of analytical methods including detection and quantification capabilities. Pure and Applied Chemistry, 67(10), 1699-1723.

Ekici, H. (2017). Undesirable factors present fish feed. Turkiye Klinikleri Veterinary Sciences- Pharmacology and ToxicologySpecial Topics. 3(2), 139-143.

European Commission (2006). Commission regulation (EC) No 401/2006 of 19 December 2006 setting maximum levels for certain contaminants in foodstuffs. Official Journal of the European Union, L364, 5-24.

Faria, C. B., Santos, F. C., Castro, F. F., Sutil, A. R., Sergio, L. C., Silva, M. V., Junior, M. M., \& Barbosa-Tessmann, I. P. (2017). Occurrence of toxigenic Aspergillus flavus in commercial bulgur wheat. Food Science and Technology, 37(1), $103-111$.

Fu, Z., Huang, X., \& Min, S. (2008). Rapid determination of aflatoxins in corn and peanuts. Journal of Chromatography A, 1209, 271-274.

Golge, O., Hepsag, F., \& Kabak, B. (2013). Incidence and level of aflatoxin contamination in chilli commercialised in Turkey. Food Control, 33, 514-520.

Goncalves, R. A., Naehrer, K., \& Santos, G. A. (2018). Occurrence of mycotoxins in commercial aquafeeds in Asia and Europe: a real risk to aquaculture. Reviews in Aquaculture, 10, 263-280.

Greco, M., Pardo, A., \& Pose, G. (2015). Mycotoxigenic fungi and natural co-occurrence of mycotoxins in rainbow trout (Oncorhynchus mykiss) feeds. Toxins, 7, 4595-4609.

Mohammadi, K., Safari, R., Khalesi, M. K., Mirmasod Sajadi, M., \& Bahri, A. H. (2018). Toxin Reviews. 37, 35-38.

Kabak, B. (2012). Determination of aflatoxins and ochratoxin A in retail cereal products from Turkey by high performance liquid chromatography. Food Control, 28, 1-6.

Kaymak, T. (2000). Detection of aflatoxin levels in trout feeds in Turkey. Master Thesis, Ankara University Graduate School of Natural and Applied Sciences, Ankara.

Kop, A. F., \& Korkut, Y. A. (2002). Quality control in fish feeed. Ege Journal of Fisheries \& Aquatic Sciences, 19(1-2), 271-276.

Korkut, Y. A., Hossu, B., \& Gultepe, N. (2002). Fish diseases related with feeding. Ege Journal of Fisheries \& Aquatic Sciences, 19(3-4), 555-564.

Maciorowski, K. G., Herrera P., Jones F. T., Pillai S. D., \& Ricke, S. C. (2007). Effects on poultry and livestock of feed contamination with bacteria and fungi. Animal Feed Science and Technology, 133, 109-136.

Merako, K. (2010). Determination of the heavy metal and aflatoxin content of the trout feeds used in trout aquaculture. Master Thesis, Namık Kemal University, Graduate School of Natural and Applied Sciences, Edirne.

Sahin, İ., \& Korukluoğlu, M. (2000). Mould-food-human. Uludağ University Enpowerment Foundation, Bursa.

Yaroglu, T., \& Gul, M. (2007). The investigation of aflatoxin b1 substance in the trout feeds in the market in Erzurum province. Van Veterinary Journal, 18(2), 51-58. 